\title{
“Colours Do Not Mix": Segregated Classes at the University of Natal, 1936-1959
}

\author{
Surendra Bhana and Goolam Vahed \\ University of Kansas and University of KwaZulu-Natal
}

\begin{abstract}
The "university" was situated at the back of Sastri College. It consisted of a small office, a well-furnished common room for the lecturers; an ill-furnished, flea-infested common room for the black students. We had a library, which we used to call "two-by-two".... tiny library and there was a prefab building. That was Natal University Non-European Section. Sum total of it! It only became alive after four 'o clock in the afternoon when the part-time students, who were in the majority, mainly Indian teachers, came from school. And we had to wait for the classrooms of Sastri College to be evacuated ...Whites had three universities, one in Pietermaritzburg, and in Durban one in Warwick Avenue and the main campus was Howard College. I spent six years at Natal University and only went twice to Howard College. ${ }^{2}$
\end{abstract}

- $\quad$ Kader Hassim

When A.H. Peters, a respected court interpreter in Pietermaritzburg, applied for permission for his son Maurice to do a pre-medical course at Natal University College (NUC) in 1921, the application was declined on racial grounds. Maurice instead left for Edinburgh and returned in 1926 as a qualified medical practitioner. He established a practice in Pietermaritzburg and holds the distinction of being the first South Africa born Indian to qualify as a medical doctor. He joined the Colonial Born Indian Settlers Association and played an active public role among Indians in the province. ${ }^{3}$

When Krish Bharatram requested admission into the Science programme at NUC, he was informed that the university could not accommodate him but that he could enrol for an Arts degree which the university offered to Black students in segregated classes. ${ }^{4}$

\footnotetext{
${ }^{1}$ An earlier version of this paper was presented by S. Bhana at a July 1985 conference in Durban when the University of Natal commemorated its seventy-fifth anniversary, for which the university and the History Department allowed access to their archival material. This is a revised version jointly undertaken by the authors.

${ }^{2}$ Kader Hassim, 24 June 2002. Interviewed by D. Shongwe, "Voices of Resistance Project”, Gandhi-Luthuli Centre, UKZN

${ }^{3}$ A.C. Meer, "I Remember”, The Leader, 20 June 1987.

${ }^{4}$ The term is used here to refer to Indians, Coloureds, and Africans collectively. These labels have not been placed in inverted commas because they were the accepted terms under apartheid and with minor alteration
} 
Determined to pursue his first love, Bharatram attended the University of Fort Hare hundreds of miles away from home. On his return to Durban after completing his degree in science, he sought admission into the Honours programme at NUC. There was some hesitation, but in the end the Physics Department accepted him as a student. He completed a Master's degree in 1966, and went on to Oxford University where he graduated with a doctorate degree. He returned to South Africa to serve with distinction the community of physicists nationally and internationally. ${ }^{5}$

The two cases were exceptions to the rule, success stories of talented Black individuals who overcame systemic flaws. There must have been countless cases of young Black men and women whose educational dreams and aspirations went unrewarded because of a wickedly unresponsive system. The cost in human emotions is incalculable. This paper examines segregation in university education with special reference to the circumstances around which separate classes were introduced for Blacks in 1936 at the NUC and continued until 1959, some nine years after the institution achieved university status. It examines the roles of various individuals, most particularly Mabel Palmer (1876-1958) who, as organizer, was instrumental in persuading politicians, administrators, and academics to run segregated classes; and of E. G. Malherbe, who as Rector of the University of Natal from 1943-1965 defended them as the only practical alternative to a segregated university. ${ }^{6}$ Palmer invested incredible energy in creating class rosters, organizing details about finances, providing instructions, and coordinating student activities, bursaries, loans, fee-remissions, and so on. She cajoled administrators and academics alike into supporting her endeavours. In Elizabeth Sneddon's words, Palmer was “the most undemocratic democrat” in getting things done. She maintained a constant stream of memoranda and letters to the principal and Senate members to make her point, and on many occasions, badgered colleagues to offer classes. ${ }^{7}$

\footnotetext{
continue into the post-apartheid period. The term "Non-European" was in use at the time.

${ }^{5}$ Bharatram related the story to S. Bhana. See also Surendra Bhana, "Natal university’s Role in Black Education: A Perspective”, Natal Convocation News \& Alumni Affairs 7, 1985, 26-27.

${ }^{6}$ Malherbe (1895-1983) was born in Luckhoff in the OFS, studied at Stellenbosch University (Higher Teacher's Diploma and MA) and the University of Columbia, New York (MA and PhD); was a founding member of the National Commission of Education (Nasionale Buro vir Opvoedkunde and Maatskaplike navorsing - later Raad vir Geesteswetenskaplike Navorsing or RGN) of which he was the first director (1929 - 1939) and he was the Chief - Editor of the Report on Poor Whites for the Carnegie Commission (1932); was Director of Census and Statistics; and Director of Military Intelligence for South Africa during World War II.

${ }^{7}$ Conversations with Elizabeth Sneddon, 4 June 1985 and Mrs. D. Kershaw, 7 June 1985; Killie Campbell Africana Library, (KCAL), Killie Campbell Museum (KCM) 18540-18541, File 42; Symposium on Mabel Palmer, 1968. Elizabeth Sneddon (1907-2005) was started and was the Head of the Department of Speech and
} 
Our argument in this paper is that liberal pragmatists worked within parameters they defined as prevailing White mores and were not prepared to challenge them. While Palmer seemed flexible if sometimes ambiguous at times, Malherbe consistently defended segregated classes for two main reasons throughout his tenure as principal. Firstly, that it was the best way to maintain academic standards since Black students came from varying educational backgrounds, and, secondly, given his belief that Black students experienced frustrations and engaged in anti-White agitation in a racially mixed environment, segregated classes ensured minimal contact of the races. That was a good thing for him. He argued that the Black student frustrations at NUC were "no greater" than those suffered in rest South Africa. In essence, his message to them was to come to terms with segregated classes. While NUC academics and administrators generally framed university education around what they imagined to be politically feasible, the Black community in general and the Black students in particular considered it a capitulation to racism. Black students felt the sting of exclusion and deprivation as Kader Hassim's statement above suggests. They insisted that race should not determine the learning process and linked the system at NUC to the whole edifice of raciallydetermined policies and practices. Their views show how deep the gulf was between them and the administrators. If many of the former students were generous in their assessment of Palmer, it is only because they considered her as much a victim of circumstances as they were, genuine in her desire to promote the education of Blacks with the tools at her disposal.

\section{Black Needs for Higher Education: The Inter-War Years}

University education was largely an urban phenomenon in Natal. Its growth accompanied urbanisation, a trend that picked up momentum after World War I with the development of manufacturing industries. In 1900, Durban's African population was 14,600 out of a total of 55,700. In rose to 28,000 in 1921 and stood at 70,000 in 1941, and would increase to 150,000 nine years later. Africans suffered from multiple disabilities as they coped with urban life. The 1923 Urban Areas Act, for example, denied them the right to freehold property in municipal townships. The limited opportunities that they had were further restricted by the 1937 Native Laws Amendment Act which sought to bar them entirely from Durban. As Whitsitt pointed out, “the whole idea of having an area proclaimed is to get 
rid of the Native inhabitants with the exception of domestic servants.”8

For Indians too, Durban was the main outlet after indenture. In 1921, there were nearly 50,000 Indians, and their number increased to 80,000 in 1936 and 100,000 in the next decade. Migrants to urban centres needed jobs, houses, and education. The Indian school population rose from 8,250 in 1925 to 35,397 in $1946 .{ }^{9}$ The opening of Sastri College in 1927, the first high school for Indian children in South Africa, increased the pool of potential university students and Indian leaders called for schools, technical and teacher training colleges, and university education which they saw as key to the "upliftment" of the community. According to an editorial in Indian Opinion in 1929, "the conditions in which the poor class of Indians have been living made it impossible for them to sufficiently educate their children, the result being that the majority of the Indians have been drifting into the various industries in Natal with little or no education at all.” ${ }^{10}$

The response of the White minority government must be seen in the context of the legacy of tense inter-racial relationships over many decades. Indians were seen potentially as a threat to White dominance from the late 1880s and the Natal legislature passed laws to curb them in all spheres of life after Responsible Government in 1893. They were singled out as an alien population not quite suited to South Africa. A warning expressed by a colonist in 1893 became a recurring theme among later generations of Whites, "Our Indians are becoming a very serious element among us. They are about as prolific as rabbits, and almost as destructive to the welfare of Europeans." ${ }^{11}$ This attitude is well illustrated in the decades after 1920 when civic and political leaders sought to prevent the so-called "penetration" of Indians into predominantly White areas. Serious efforts were made nationally and locally to repatriate Indians, if not directly by law then indirectly by offering financial inducements and subjecting them to discriminatory treatment. ${ }^{12}$

\footnotetext{
${ }^{8}$ Paul Maylam and Iain Edwards, eds. The People's City: African Life in Twentieth Century Durban (Pietermaritzburg: University of Natal Press, 1996), 6, 7, 9, 14.

${ }^{9}$ Frene Ginwala, “Class, Consciousness and Control: Indian South Africans, 1860-1946.” (Ph.D. dissertation, Oxford University, 1974), 292.

${ }^{10}$ Indian Opinion, 22 May 1929.

${ }^{11}$ In Maynard W. Swanson, “The Asiatic Menace: Creating Segregation in Durban, 1870-1900,” International Journal of African Historical Studies (16, no. 3, 1983), 401-21.

${ }^{12}$ See Swanson, “The Asiatic Menace: Creating Segregation in Durban”; Surendra Bhana, Gandhi's Legacy: The Natal Indian Congress, 1894-1994 (Pietermaritzburg: University of Natal Press, 1997), 55, 107; Ashwin Desai and Goolam Vahed, Inside Indenture: A South African Story, 1860-1914 (Durban: Madiba Publishers,
} 
In an attempt to resolve these tensions, a Round Table conference was convened between the governments of India and South Africa in December/January 1926/27. The outcome was that the Indian Government agreed to a scheme for the voluntary repatriation of Indians; the South Africa Government promised to "uplift" the social and economic position of those who remained; and the Indian government was to appoint an Agent to monitor the workings of the Agreement and to facilitate relations between Indians and the Union Government. The Agent's task included facilitating contact with sympathetic Whites. ${ }^{13}$ Sir Srinivas Sastri, a key member of the Indian delegation, accepted that "the European mind must be relieved of the fear of being swamped by an excess of Indians” and that Whites had sacrificed enormously to attain a "western" standard of life and had the right to protect it. ${ }^{14}$ "Western standards" were never defined. The rationale was never openly expressed, but a thread that runs through the discourse is that Whites had to maintain a self-defined standard in all walks of life, especially in educational institutions, and allowing Blacks into schools and universities would compromise these standards. Notwithstanding the Agreement, Whites became increasingly frustrated because too few Indians repatriated and racial tensions continued to simmer through the 1930s and especially the 1940s. It is in this context that we must locate segregation at the NUC. Nothing materialized in terms of assistance from the Council. These were the conditions then, under which the issue of admitting Black students to NUC came up.

\section{Segregated Classes at NUC}

NUC had received a few enquiries from Indian students in the 1910s. M.H. Vahed of Pinetown made enquiries about admission in 1916; A.H. Peters, as mentioned above, wrote for admission to a pre-medical course in 1921; and there was an application to study for a BA degree in Pietermaritzburg. The university declined the applications. ${ }^{15}$ In 1928, the newly appointed Principal, John W. Bews suggested the creation of two additional colleges, one for Africans at Adams Mission and another for Indians at Sastri College, which together with the

\footnotetext{
2007)

${ }^{13}$ U.S. Mesthrie, "From Sastri to Deshmukh: A Study of the Role of the Government of India's representatives in South Africa, 1927-1946," Ph.D. thesis, University of Cape Town, 1984, 60-65.

${ }^{14}$ V.S. Sastri, "The Cape Town Agreement: Its Full Significance," The Hindustan Review (April 1927), 190.

${ }^{15}$ Edgar H. Brookes, A History of the University of Natal (Pietermaritzburg: University of Natal Press, 1966), 44.
} 
Pietermaritzburg and Durban campuses would make up four separate constituent colleges. ${ }^{16}$ That nothing came of the proposal was probably due to the fact that the government was lukewarm to promoting university education in Natal and appointed the Van der Horst Commission to look into higher education in the province. Its report in July 1928 was followed by a conference convened by Dr. D.F. Malan, Minister of the Interior, Education and Public Health, in January 1929. The conference resolved that Durban should become the university centre in Natal and that the Technical College abolish its university activities. It said little about meeting the needs for Black students. ${ }^{17}$

The question of higher education for Blacks came up again in 1933 when the university received two applications from students at Sastri College. Bews informed Sastri principal W.M. Buss that no provision could be made because of the fear of upsetting White students and benefactors. Around October 1934, the new Agent-General Kunwar Sir Maharaj Singh raised the issue in a meeting with Bews. This was discussed at a Senate meeting on 6 November 1934 and a motion that Bews be given the discretion to include Blacks was defeated. ${ }^{18}$ Mabel Palmer's suggestion that Senate establish a Committee to formulate a plan to accommodate Black students was accepted. ${ }^{19}$ Council appointed a second committee with Maurice Webb as convenor. The Palmer Committee reported to Senate and the Webb committee to Council on 15 March 1935. Both committees were sympathetic to accommodating Blacks but the meeting in Council was a "stormy one" and in the face of opposition, especially from representatives from Northern Natal, a compromise proposal was accepted that, since the admission of Blacks as full-time residential students was not "practicable," segregated part-time classes be organised for Blacks. ${ }^{20}$ Only Webb and Michaelhouse Rector, R.F. Currey, were in favour of mixed classes. Although it was decided to provide segregated classes for Black students on both campuses, they were only started in Durban. $^{21}$ According to Brookes, Council "proved adamant against the admission of

\footnotetext{
${ }^{16}$ Brookes, History of the University of Natal, 46.

${ }^{17}$ Wyn Rees, The Natal Technical College 1907-1957. A Jubilee History. (Pietermaritzburg: The University of Natal Press, 1957), 200-7.

${ }^{18}$ Sylvia Vietzen, “Mabel Palmer and Black Higher Education, 1936-1942”, Journal of Natal and Zulu History, (6, 1983), 98-114, 99.

${ }^{19}$ Brookes, History of the University of Natal, 45. The committee included Dr. Bush, Mabel Palmer, Professor Whittaker and Florence MacDonald.

${ }^{20}$ Vietzen, "Mabel Palmer", 99-100.

${ }^{21}$ George W. Gale, John William Bews: A Memoir (Pietermaritzburg, 1946), 80-81, 83-84; K.P. Naidoo: "PostPrimary Education for Indians in Natal, 1927-1952” (MEd. thesis, UNISA), 156-158. The members of the Senate committee were: Palmer, Bush, Whittaker, and Florence Macdonald; and the Council committee's members were: Webb, Bews, Currey, C.E. James, H.E. Jones, G. Davis, Leif Egeland, W. Falcon, and Adams
} 
Africans, Asians or Coloured people to the ordinary classes and buildings of the College. The least line of resistance was to accept this ruling [of segregated classes]...”22 A joint committee from Senate and Council was elected to put the motion into segregated Black classes.

Mabel Palmer gave up her lectureship at the university and focused on the NonEuropean University. Her official designation was “Advisor”, which changed to "organizer” in 1940. The experiment started in May 1936 on the Durban campus with 19 students who were offered five subjects, English, Zulu, Geography, History, and Economics, and continued until 1959. ${ }^{23}$ To provide a sense of “academic life”, a Winter School was held over a fortnight every July when teachers were on holiday. Palmer's biographer Sylvia Vietzen described the early years:

\begin{abstract}
Classes at inconvenient places and times such as Friday evenings, all day Saturday and Sunday mornings at hutments in Sastri College, reached in all weather by rickshaw; using her home as the office; giving her services free for the first three months, and for little more after that; submitting the balance sheet in her own hand on a yellow writing pad; lending her own books and forwarding the fees..., 24
\end{abstract}

Who was Palmer? She had come to South Africa with a record of academic excellence and considerable experience in teaching. She was born in 1876 and was one of the first women graduates of Glasgow University where she read Philosophy and Classics. She subsequently did graduate studies at the London School of Economics, wrote for the London Daily News, lectured in Economics at King's College at the University of London, and held a Workers' Educational Association tutorship. She was an ardent feminist who was involved in the Fabian Society and participated in the suffragette movement. In 1914 she married an Australian and lived in Sydney after the war. Her marriage failed and she accepted a lecturing position in Economics at the Durban Technical College where she was placed in charge of the Workers' Educational Association. She transferred to Natal University College as lecturer in Economic History when Howard College opened in $1931 .^{25}$

College Principal Edgar Brookes. University of Natal Archives (UN Archives), 15 February 1935, 13/13:

Subcommittee on Non-European Students. KCAL, KCM 18540-18541, File 42, see also Symposium on Mabel Palmer, 1968.

${ }^{22}$ Brookes, History of the University of Natal, 45.

${ }^{23}$ I.C. Meer, "I Remember. Reminiscences of the Struggle for Liberation and the Role of Indian South Africans1924-58.” Edited by Enuga S. Reddy and Fatima Meer (unpublished), 83.

${ }^{24}$ Marks, Not Either an Experimental Doll, 5.

${ }^{25}$ See Shula Marks, Not Either an Experimental Doll: The Separate World of Three South African Women 
According to Rees, Palmer was "undoubtedly the most highly qualified person yet to join the staff of the Technical College - and certainly one of the most gifted.”26 She became involved in the Joint Councils that liberal Whites had established separately with Indians and Africans to foster good relations, and joined the Institute for Race Relations in 1929.

Palmer took on the daunting task of providing Blacks with some university education when she was already sixty. In the early years, it was difficult to make up the required numbers to offer courses as there were barely six matriculated Blacks, recalled Ian Allan her successor. Yet, nothing was insuperable to Mabel Palmer. There were 19 students in 1936, (11 Indians, 6 Africans, and 2 Coloureds), 69 (7 Africans, 2 so-called Coloureds, and 60 Indians) in 1940, 136 (12 Africans, 4 so-called Coloureds, and 120 Indians) in 1945, and 222 (57 Africans, 9 Coloureds, and 156 Indians) in 1950. There was a spurt in university registrations in the late 1950s as it became difficult for Indians to attend Wits University and Fort Hare. 558 students were registered in 1960. This included 193 male and 48 female fulltime students (44 percent), and 317 (men and women) part-time students. The proportion of full-time students increased steadily as it was only 22 per cent in 1954. By 1960, the university had awarded over 650 degrees in Arts and Social Sciences, and 85 doctors had graduated from the Medical School. ${ }^{27}$

The system initiated by NUC was unique in South Africa. The University College of Fort Hare was established for Black students and admitted Indian students from the early 1920s. ${ }^{28} \quad$ Afrikaans-language universities like Orange Free State, Potchefstroom, Stellenbosch, and Pretoria excluded Black students altogether. English-language universities like Witwatersrand University (Wits) and University of Cape Town (UCT) admitted Black students from 1936. However, as various studies have shown, Black students were excluded from various social activities, living in campus residences, and were sometimes disadvantaged academically. Bruce Murray has written that while Wits was an 'open university', its “doors never much more than half open to Blacks.” Faculties like Dentistry were never opened to Blacks, while a quota system was introduced at the Medical School

(Bloomington: Indiana University Press, 1988), 3-7.

${ }^{26}$ Rees, The Natal Technical College 1907, 97.

${ }^{27}$ Between 1938 and 1963, there were 666 Black graduates and 163 holders of Unversity diplomas. This included 4 Ph.Ds, 14 MAs, and 42 Honours degrees. Brookes, History of the University of Natal, 76.

${ }^{28}$ Mabel Palmer, "Higher Education in Natal", African Affairs, (50, no. 199, 1951), 134-35 
from 1953-54. ${ }^{29}$

In social and sporting spheres, the University's official policy was to apply the "colour bar". ${ }^{30}$ As the example of Ralph Lawrence and his contemporaries show, Blacks were disadvantaged in certain academic activities at UCT. Durban-born Lawrence's experience at a university that subscribed to "academic non-segregation” influenced him to leave South Africa. In May 1944, when he was in his clinical year in the Medical School at the UCT, he was suspended for violating a university regulation that prohibited him from being present at the examination of White patients, and hauled before a university disciplinary court. The panel excused Lawrence only on the grounds that he had failed to comply because of a misunderstanding. A month later, he and the other Black students received letters informing them of a formal university council decision that they were barred from "any class, clinic, clinical lecture, demonstration, operation or post mortem where a European patient was present.” After graduating Lawrence left for England where he has had a distinguished career in medicine for which he was awarded an OBE. ${ }^{31}$ Lawrence's experience was shared by Dr. Yusuf Motala who matriculated from Sastri College in 1939 and went to study medicine at UCT, where he was a contemporary of Ralph Lawrence. He recalled:

\begin{abstract}
In the second year we went to medical school and did Anatomy and Physiology. There was apartheid there too - they won't allow us to have a white body, to do post mortems on white body. And then when we went to the hospital, if they had a demonstration, clinical demonstration, and if it was a white patient we were not allowed. If it was a white patient, you must walk out. And if they put outside "NE”, Non-European, then you can go in - it's alright. What broke the back was the fact that now they even objected to post-mortems. If it was a white post-mortem, you can't go, so even the dead Whites objected to our presence there. I was getting fed up .... and even some of the lecturers sometimes, they will take the white students and talk to them and educate them, tutor them but ignore you.
\end{abstract}

Motala "could not handle the discrimination" and left UCT for St. Georges, Hyde Park, in London where he qualified as a medical doctor. ${ }^{32}$ Motala returned to South Africa and

\footnotetext{
${ }^{29}$ Palmer, "Higher Education in Natal”, 134-35. See also S. Bhana, "University Education for Indians," In Bridglal Pachai, South Africa's Indians: The Evolution of a Minority. Washington: University Press of America, 1978: 384-440; H.W. van der Merwe and David Welsh, The Role of the University in Southern Africa. Cape Town: David Philip, 1977; Bruce K. Murray, Wits the 'Open Years'. A History of the University of the Witwatersrand, Johannesburg 1939 - 1959. Johannesburg: Witwatersrand University Press, 1997; and Mervyn Shear, Wits. A University in the Apartheid Era. Johannesburg: Witwatersrand University Press, 1996.

${ }^{30}$ See Bruce K. Murray, "Wits as an 'Open’ University, 1939-59: Black Admissions to the University of Witwatersrand,” Journal of Southern African Studies, Vol. 16, No. 4 (December 1990): 649-767.

${ }^{31}$ Ralph A.A.R. Lawrence, A Fire in His Hand (London: Athena Press, 2006), 35.

${ }^{32}$ Dr. Yusuf Motala, 26 October 2009. Interviewed by Goolam Vahed. Motala was born in 1917 in Greytown
} 
served the local Durban community for many years.

As a Fabian socialist, Palmer worked for change on the basis of gradualism within existing frameworks, and if segregated classes were the only means then available, she was prepared to work with them. Her ultimate aim, according to her close friend and associate Florence Macdonald was "complete integration of people of equal ability." "Take what you can get and work towards development," was Palmer's belief, according to Macdonald. "Half a loaf is better than no bread," Palmer wrote in the Daily News in 1957, and explained that she had accepted segregated classes in the belief that "the professors and lecturers would object to duplicating their lectures and would in the end insist on the admission of nonEuropeans to the ordinary classes." 33 Dr. Goonam, who qualified as a doctor in Edinburgh in 1934, described Palmer as “a very important person. She’s the one who brought about higher education.... Until then our people did not have higher education. That's a tremendous contribution.... She had a good heart, a very good heart.”34 Palmer had a strong influence on some of her female students.

Fatima Meer, who was enrolled for an Arts degree in the late 1940s, was a member of the Black SRC. She and others like her attended the university under protest, and therefore showed their displeasure by boycotting extracurricular activities. In any event, they were denied participation in sports activities. They could not wear the university blazer and the proffered excuse was that only members of athletics clubs could wear it. Palmer once arranged for the students to attend a local production of a Shakespeare play. Meer led a boycott, and when Palmer accused her of being hypocritical since she attended the university, she rebutted that they were forced to do so because they needed an education, but that attending the play was a choice that she did not exercise. Meer nevertheless holds Palmer in high regard:

[...] a radical who had an enormous impact on me personally, and even more so on Ismail [C. Meer], J.N. [Singh] and their [Liberal Studies] Group. So I would not be critical of her. But for her, many of our people would not have had degrees, no university education. And she

\footnotetext{
and was 92 at the time of the interview. Motala died about a month after the interview, on 1 December 2009.

${ }^{33}$ KCAL, KCM 16776, File 1, Mabel Palmer Papers.

${ }^{34}$ Vanessa Noble, "Ruffled Feathers. The Lives of Five Difficult Women in Durban," (BA Hons., Pietermaritzburg: University of Natal, 1997) 125.
} 
was prepared to listen to our protests. ${ }^{35}$

Aside from the classes, Palmer also founded the Liberal Club in Foundry Lane just off West Street, which, in some sense, replaced the previous Liberal Studies Group which had become dormant by the late 1940s:

\begin{abstract}
This was one of the few places where people of all races could meet. They could have lunch and all kinds of talks were held there, and dramatic and musical performances where Blacks participated. Luthuli would sometimes attend, C. K. and Jean Hill, the NIC people like Debi Singh and A. I. Meer .... Ismail [Meer] was one of the early students at the university. He told me that Mabel Palmer would teach several subjects, History, Economics, Politics. She even started Law classes with Ismail, J.N. and Ismail Bhoola but the Law society put an end to that as they did not want competition. We mostly saw Mabel Palmer in a positive light. She spoke to us about the Fabian Society. I remember she had a photo of herself, George Bernard Shaw, Beatrice and Sydney Webb, all going hiking, she showed it to us and spoke of about Fabian ideals. $^{36}$
\end{abstract}

Phyllis Naidoo spent many years in exile and suffered the loss of her son at the hands of the apartheid regime. Naidoo was a teacher at Briardene when she undertook her university studies. She earned around $£ 9$ monthly, out of which she paid $£ 5$ in rent, and an annual university fee of $£ 4$. Naidoo approached Palmer for fee remission. Palmer did not grant this. Instead she wrote to Phyllis' father, her former student, to stand guarantor for the fee. In the end, Naidoo was able to pay off her fees without help. She remembers Palmer as a "big broad person ... a strong woman. Remember she comes from a different generation. She was tough on me but could have been worse. Her history lessons were brilliant.” When Palmer began to lose her eyesight, she asked Phyllis to read history books and literature to her. "When I read to her, she would ask me to interpret what I was reading. And then she would give me her interpretation. She had a fantastic knowledge. I learnt a great deal from her and in many ways she helped shape me.” ${ }^{37}$ Asked what Palmer's greatest contribution was, Naidoo replied, “Oh, her opening up education. You know, pathetic as it was, stuck at the back of Sastri College, and all those things, you can be very critical of those things, but she made it possible.”38

As a pragmatist, Palmer was not above using paternalism in her communications with people in power. In a 1942 letter to J.H. Hofmeyr, then a member of J.C. Smuts'

\footnotetext{
${ }^{35}$ Fatima Meer, 2 November 2009. Interviewed by Goolam Vahed.

${ }^{36}$ Ibid.

${ }^{37}$ Phyllis Naidoo, 3 November 2009. Interviewed by Goolam Vahed.

${ }^{38}$ Noble, "Ruffled Feathers", 176.
} 
government, she argued for "parallel facilities” for Indians with minimal contact with Whites:

\begin{abstract}
My own view is that while nothing in the nature of definite 'segregation' is possible, there should be an effort at developing parallel facilities for Indians with a minimum of close contact with Europeans. This is the policy which has on the whole, turned out to be successful in dealing with the problem of university education for non-Europeans, (mainly Indians in Natal). Although the University College authorities have not I think, since the death of Dr. Bews, accorded to the Indians the generosity and consideration which might have been expected, still it might be said that the experiment has worked well, and it is a somewhat similar policy that I should like to see adopted in dealing with the Indian situation as a whole. $^{39}$
\end{abstract}

Her ambivalence towards integrated education shows. In a 1951 article, she defended "segregation within the university" or "parallelism" as the best option in Natal. There were practical reasons for this. She explained that most of the students were teachers, many from out of Durban, who could only attend part-time classes which were held mainly on Friday afternoons, Saturdays and Sunday mornings to accommodate student needs. This continued until the end of 1951. Students not living in Durban spent Friday and Saturday nights in the city with relatives. $^{40}$ Part-time classes were also necessary because few students were supported by parents. Students whose parents were affluent usually studied at Fort Hare or medical schools in India, Edinburgh, and England. The Thumbadoo brothers are a good example of this. At the time that they were attending the university in the 1940s, George was a teacher at Sastri College; Rad was teaching at Clairwood High, and Teddy was a teacher at Carlisle Primary. Rad, who completed an Honours degree in English, was one of the sixteen students who boycotted the graduation ceremony in 1951. With his three brothers working, Rama was able to attend Fort Hare where he studied for a Science degree, and took up a position at the newly opened Springfield College for teacher training. After completing his degree, George was promoted as principal to Mandini School and later of S.M. Jhavary; Rad taught at Tanjore, St. Aidans, Clairwood High, the M.L. Sultan Technikon, and Sprinfgield College; Teddy taught at Greyville School, Dundee High School, and was appointed principal of Newcastle High School. ${ }^{41}$ The family thus played a crucial important supportive role in Indian education.

Another student who attended segregated classes was M.D. Naidoo. Naidoo was born

\footnotetext{
${ }^{39}$ Palmer wanted to serve on the Lawrence Committee then about to investigate the so-called "penetration" of Indians into White areas. KCAL, KCM 16776, File 1, Mabel Palmer Papers, letter to J. H. Hofmeyr, 28 October 1942.

${ }^{40}$ Palmer, "Higher Education in Natal”, 134-39.

${ }^{41}$ Rama Thumbadoo, 2 November 2009. Interviewed by Goolam Vahed.
} 
in 1919 and forced into employment at an early age. He was drawn to the Communist Party and Liberal Studies Group in the 1930s and began reading about history and socialism "more out of a hunger for knowledge than anything else.” Poverty and mobilisation on the anti-war issue sharpened his political consciousness. Naidoo got a job with the Central News Agency and completed his schooling through correspondence. He lost his job when he requested leave to write the final matriculation examination in 1940, and became a full-time union organizer. In 1943 he registered at the NUC and was elected to the student body. After graduating, Naidoo eventually made his way to London where he completed a degree in Law. He would be a key figure in anti-apartheid politics and spent five years on Robben Island from 1966 before going into exile. ${ }^{42}$

Palmer described the average Black student as "more mature" but academically “defective” relative to Whites because they lacked access to reading material at home and the quality of their school education was poor. Their commitment, however, could not be faulted. She wrote that "the sacrifices they make for education are amazing. Some have to rise at 3 a.m. on Saturdays in order to be in time for their classes and, after a strenuous weekend, they resume teaching again on Monday mornings.” ${ }^{33}$ Dr. Yusuf Motala could attest to this:

When I got there [UCT Medical School] I didn't know anything about Physical Science, Chemistry - they never taught us that at Sastri College - they taught us Botany. Botany was only a six months course but Chemistry and Physics we didn't know. So the first year we were completely lost - elementary things they'd put on the board, we didn't know. Anyway some of the people were sympathetic - the Afrikaners - they were sympathetic and taught us privately. $^{44}$

Palmer was aware that "Non-European opinion is generally against even this modified form of segregation and accepts it only under protest” but argued that it was the only "practicable" option because "racial sentiments in Natal would have virulently resented the entry of Indians, Africans, and coloured into the ordinary classes of the university." 45 Palmer’s 1957 book on Indians devotes just two paragraphs on university education among Indians and makes no comment on the rationale for segregated classes and certainly does not

\footnotetext{
${ }^{42}$ A separate Black SRC was formed in 1948. According to Brookes, "a non-European described sat on the Durban S.R.C. in1943.” This was most likely M. D. Naidoo. Brookes, History of the University of Natal, 165. M.D. Naidoo, c. 1986. Interviews by Julie Frederikse. Housed at William Cullen Library, Wits University.

${ }^{43}$ Palmer, "Higher Education in Natal”, 135-36.

${ }^{44}$ Dr. Yusuf Motala, 26 October 2009. Interviewed by Goolam Vahed.

${ }^{45}$ Palmer, "Higher Education in Natal”, 136.
} 
declare her principled opposition to them. ${ }^{46}$ According to Marks, Palmer reconciled "segregated classes with her conscience by drawing an analogy with the separated male/female classes which she had experienced in Glasgow.” As the first group of students who were mainly schoolteachers seeking to upgrade their qualifications, "they were willing to accept the inequalities and humiliations of a separate and inevitably unequal system." ${ }^{47}$

Palmer desired to place segregated classes on a proper structural footing so that they could enjoy the support of the university principal and other governing members of the institution. It was, as Florence MacDonald recalled in 1968, part of Palmer's strategy to get as many people as possible involved in the running of classes through university committees, of which there were three important ones. ${ }^{48}$

The first committee was the Non-European Studies Committee (NESC) of 1940, ${ }^{49}$ whose powers and constitution were established in 1944 when it became a Senate committee with a Senate member acting as chairperson. NESC had originally reported to the Principal. Its function was to liaise with the organizer (Palmer) in the planning and executing of courses offered to Black students. The committee's composition was multi-racial. In 1948, it was expanded to include representatives of part-time lecturers, the Natal Education Department (NED), and Sastri College. It was further revised and expanded in 1950 to include one representative from each of the faculties involved in segregated classes including the newly created Medical School, two instead of one representative from the NED, one for African schools and one for Indian schools, two persons elected from among the staff of the NonEuropean Section instead of one, and ten persons appointed by the Senate. ${ }^{50}$

The second committee involved in the running of segregated classes was the NonEuropean Advisory Finance Committee (NAFC). The state subsidy went directly into the Black section. The accumulated credit at the end of 1941 w£2194. In 1945, a

\footnotetext{
${ }^{46}$ Mabel Palmer, The History of the Indians in Natal (Westport, CT: Greenwood Press, Publishers, 1977, reprint of OUP 1957 ed.), 167-69.

${ }^{47}$ Not Either an Experimental Doll, 5-6.

${ }^{48}$ KCAL, KCM 301, Interview with I. K. Allen, 18 September 1980; conversations with Ian Allan, 10 June 1985; UN Archives, Non-European Studies Committee (NESC) files, Annual Reports of the Organizer.

${ }^{49}$ It was officially designated by Senate in 1940 as the Advisory Committee for Non-European Studies, although it was generally referred to as the Non-European Studies Committee.

${ }^{50}$ UN Archives, File 12/5, File 12/13 NESC Committee of Non-European Class, 23 November 1937, 11 June 1940, 5 June 1944; UN Archives, File 21/2, Advisory Committee to Council on Non-European Affairs, 1 May 1953.
} 
subcommittee recommended that the finance committee was not necessary, and advised that all finances dealing with segregated classes be handled by the NUC's administration as normal student revenues. Palmer responded that it would only make sense to abolish the finance committee if the intention was to eliminate segregated classes for "full participation of the Non-European communities in university organization and administration including Non-European membership of the Faculties, Council and Senate...”. Since that was not the case the committee should be retained to continue raising funds. Palmer's argument prevailed. It is not clear whether NAFC continued to function as a separate body through the 1950s. ${ }^{51}$

The third important committee was the Advisory Committee to the Council on NonEuropean Affairs. First mooted in December 1949, its function was to advise the Council on general policy matters affecting the Black section, and to deliberate on such aspects as raising funds for bursaries and loans, recommending fee remissions, organising hostel accommodations, and running vacation schools. In May 1953, a university subcommittee recommended that this Committee should have no say in general university policy. The Committee's primary function, it appears, was to create links with civic, educational, and business leaders, particularly in the Black communities. Two doctors were included in the Committee since the Medical School Board wanted to see greater contact between Black communities and the Medical School. Palmer was central to all these committees, since, as Florence Macdonald remembered, there was “nothing passive about her.” 52

Except for some graduate courses which were offered on a non-segregated basis, the undergraduate courses presented many difficulties. A major weakness was the limited range of courses and degrees available to Blacks. Most of them were in the Arts faculty. Some heads of departments were located in Pietermaritzburg where there were no facilities for segregated classes, and some courses were available only there. Between 1938 and 1949, 148 degrees were awarded, of which 143 were BA’s, and three graduate degrees. There was

\footnotetext{
${ }^{51}$ UN Archives, File 13/13, Non-European Advisory Finance Committee, File 12, Subcommittee Report, 23 May 1945, and Palmer's response on 2 August 1945. The subcommittee consisted of H. R. Jones (convenor), Alan Hattersley, Maurice Webb, and H.R. Burrows. The basic subsidy formula as assessed in 1955 did not reward all the departments and sections in the university. The government subsidy to UN was for 32 departments only. See University of Natal Gazette June 1955.

52 UN Archives, File 21/2, File 9/13, Committee of Council on Non-European Affairs: Minutes of Finance and General Policy Committee meeting of 6 December 1949; Memorandum on Committees dealing with NonEuropean Courses and Students, 1 May 1953, and a Subcommittee Report, 11 May 1953.
} 
only one graduate in Commerce, and another in the Social Sciences. An NESC assessment in 1949 revealed that Law was not available to Black students except to a handful doing the attorney's admission examination by special arrangement through the Pietermaritzburg campus.

The Education faculty was unable to offer diplomas or degrees partly because Black teachers' colleges were not available for training purposes. The Commerce faculty offered a restricted selection of courses and saw no possibility of extending them. The Science and Engineering faculties could not accommodate Black students on the Durban campus because of insufficient laboratory facilities and staff. ${ }^{53}$ The situation eased somewhat in the 1950 s as some courses were gradually opened in Commerce and Law. However, Science remained closed to Blacks except in subjects related to the Medical School which was opened in 1950. Palmer was very keen that Blacks should be offered science courses. It would be a good thing, she said in 1944, that Black attention should focus on "factual subjects into which question on racial differentiation” did not enter, because literary and philosophic subjects led Indians to discuss "their racial disabilities". The non-availability of Science courses was deemed to be “a matter of serious reproach,” according to Palmer's successor Ian Allan. ${ }^{54}$

The shortage of staff was another major weakness. In the early days, part-time lecturers taught classes or fulltime lecturers who were imbued with a "missionary spirit" or who otherwise became Palmer's “charmed victims”, in Ashwin Choudree's words, and worked on Friday evenings, all day Saturday, and Sunday mornings. ${ }^{55}$ As the numbers grew, and a part-time White section was established in 1941, lecturers had to duplicate and even triplicate lectures. This interfered seriously with their leisure and research activities, especially after 1947 when they were required to teach both sections. Palmer was fully aware of this and suggested in September 1949 that lecturers should alternate annually, giving classes only to Blacks one year and to Whites the next. NESC vetoed this suggestion as it did not think the system would work. The concern in the Arts faculty in 1949 was whether

\footnotetext{
${ }^{53}$ UN Archives, File 9/13, Annual Report for 1949; A. Choudree recalled in 1968 that the Law Department agreed to give law lectures in Durban, and to avoid duplication, the Black and White classes were combined in an attorney's office. KCAL, KCM 18540-18541, File 42; Symposium on Mabel Palmer, 1968; NESC meeting, 9 September 1949, File 12/13 (new file number is 29/15/9). See also UN Archives, File 13/13, Non-European SRC Correspondence, 28 September 1949.

${ }^{54}$ UN Archives, NESC, File 12/13, Palmer's memorandum on future development, 8 November 1944; conversations with Ian Allan, 10 June 1985.

${ }^{55}$ KCAL KCM 18540-18541, File 42, Memorandum by T. H. Kelly in 1953 suggesting that classes for Whites in City Buildings were started in 1936, information by Cochran, 19 June 1985.
} 
uniform academic standards were being maintained. A resolution was adopted on 4 November 1949 that Senate investigate the matter, and obtain from Council "a clear outline of policy with regard to the Non-European studies, including the adequate provision of staff, accommodation, libraries, and travelling facilities for staff and students”. ${ }^{56}$

Additionally, there were serious difficulties regarding suitable venues for lectures and libraries. In the early days, Sastri College served as a venue for weekend classes. A library was erected in Commercial Road. Specially built huts behind Sastri College in 1946 were used as office, common room, and library until 1958. In 1959, the university acquired an old warehouse known as Marian Buildings in Lancers Road, opposite the City Buildings, which, for years had been used for part-time classes for Whites. It was inadequate as a venue. There was, according to Leo Kuper, “a deep sense of deprivation at Marian Buildings made all the more painful by the extensive academic and occupational opportunities and the infinitely better educational facilities for White students at the same university." ${ }^{57}$ Paul David, a future leader in the NIC and United Democratic Front who attended the university from 1959, points to the sheer determination to get an education saw them through such conditions:

\begin{abstract}
We were in a Warehouse, Marian Building. It was privately owned. Opposite was the City Building which housed the Accountancy section and library for black students. Eventually the Law Faculty moved there but that was only in 1964. By that time there were very few black students. A factory called Leading Lady ... they manufactured ladies clothing ... were on the ground floor. We were on second and third floors. The acoustics were terrible. They stuck hessian sacking to avoid reverberation. There was nothing high tech but we stuck it out as we went there to get an education. That was uppermost in our minds. Our parents were great pushers, you know, 'education was the only way out,' they told us. There was no campus-like atmosphere which the white students enjoyed. We had a Common room of sorts, nothing much. And it was a really busy place, a built-up place with buses, a pub. We were right next to Warwick Avenue. People branched off from here to all areas so it was really bustling. ${ }^{58}$
\end{abstract}

Zubeida Seedat, a student in the late 1950s and early 1960s, points similarly to difficult conditions for students. "Some lecturers were difficult," she continued, "but, you know, you carried on with your work. But there was absolutely no interaction ... you went

\footnotetext{
${ }^{56}$ KCAL KCM 18540-18541, File 42, Memorandum by T. H. Kelly in 1953 suggesting that classes for Whites in City Buildings were started in 1936, information by Cochran, 19 June 1985; Symposium on Mabel Palmer, 1968; UN Archives, File 12/13, NESC Correspondence to 1949. The Arts faculty suggested a subcommittee consisting of T. H. Kelly (convenor), J. D. Krige, G. S. Nienaber, and J. McKinell.

${ }^{57}$ UN Archives, File 9/13, NESC Correspondence to 1949, 25 June 1948, 5 October 1948; Vacation School, File 10/13 [new number: 1/10/11]; UN Archives, File 21/3 NESC 1959 Report; Mabel Palmer Papers, KCAL KCM 18263, File 35; Leo Kuper, An African Bourgeoisie: Race, Class, and Politics in South Africa (New Haven: Yale University Press, 1962), 155.

${ }^{58}$ Paul David, 4 November 2009. Interviewed by Goolam Vahed (telephonic).
} 
for your lectures, you came back, there was no real campus life as such because it was segregated, so that part you just missed ... you didn't have this existence at all." ${ }^{59}$ David and Seedat highlight that the makeshift nature of the venues and poor library facilities segregated from the main campus militated against the development of a corporate sense of belonging to the university.

The vacation school organized annually in July at Adams College was aimed at giving students "those factors of a university life... which are inevitably lacking in our hurried courses", said Palmer in 1948, or as she put it more succinctly in 1952, to supplement "the unavoidable deficiencies of the part-time classes for Non-European studies”. ${ }^{60}$ The Winter School included lectures, sports, as well as guest talks by well know public figures. ${ }^{61}$ Phyllis Naidoo and her father Simon David both attended the Winter School. While the experience was "good", she described the accommodation in mid-winter as "trying." Many Black students appreciated this, but as the Black SRC pointed out in 1953, vacation school became necessary only because the university practised racial discrimination, and denied Blacks equal access to all its facilities. ${ }^{62}$ The Winter School lasted from 1937 to 1952 when pressure from Black students who felt this merely reinforced segregation put an end to it. ${ }^{63}$

Given the difficulties inherent in segregated classes, why were they allowed to continue? Two committees considered this question. In 1945, the NUC appointed a subcommittee consisting of H. E. Jones, Alan F. Hattereley, Maurice Webb, and H. R. Burrows to formulate future policy with regard to the Black section. This committee was appointed in response to two memoranda that the Non-European Student Union submitted to the Natal Indian Judicial Commission then investigating Indian educational needs. The memoranda were critical of the university education system in general and segregated classes in particular. "We firmly believe that to keep to the true spirit and tradition of a university," the students stated in the first memorandum, "South African universities should throw open their doors to all sections of the populations in the country." This would help build

\footnotetext{
${ }^{59}$ Zubeida Seedat, 17 February 2009. Interviewed by Goolam Vahed.

${ }^{60}$ UN Archives, Vacation School, File 10/13, 23 December 1948, five new number 2/10/127; Memorandum by Palmer, 26 March 1952, File 10/13; Non-European SRC memorandum on Vacation School, 24 March 1953, File 12/3.

${ }^{61}$ Brookes, History of the University of Natal, 45.

${ }^{62}$ UN Archives, Vacation School, File 10/13, 23 December 1948, five new number 2/10/127; Memorandum by Palmer, 26 March 1952, File 10/13; Non-European SRC memorandum on Vacation School, 24 March 1953, File 12/3.

${ }^{63}$ Rama Thumbadoo, 2 November 2009. Interviewed by Goolam Vahed.
} 
"harmonious relationship between the various race groups." Indians did not want "Indianisation but South Africanisation" with a university training that made them "less alien, less unprivileged and less unintegrated into the structure of South African society.” They made specific points of criticism about Black classes, but insisted that those problems arose because of segregation. The second memorandum dwelt on education's position in the wider society. The students said that they desired an elimination of racial prejudice from social life so that education would not become contaminated by it. ${ }^{64}$

Deans and, in some instances, heads of departments involved in segregated classes were asked to respond to these criticisms. They wanted some factual inaccuracies corrected, but mainly they felt betrayed by the "uncharitable" attitude of the Black students. A subcommittee, whose members were the same as the one in 1945, was asked to respond. They corrected some errors, supported the Black students' right to wear college colours, and argued that the memoranda were concerned with public policy rather than NUC policy, and therefore did not warrant a reply. In formulating a long-term policy, the 1945 subcommittee visualised a university with "federal" status based at Adams College as an affiliated college for Africans. As for Indians, the subcommittee recommended, "It should be our aim to establish a parallel institution on a suitable site and to open negotiations with the Indian community with a view to establishing a residential Indian University College”. It suggested that the Sultan Technical College about to be completed should be given the same status as the one proposed for Adams College. NUC should run a Medical School predominantly for Blacks but also open it to a few Whites. The subcommittee suggested separate residential hostels for Africans and Indians. In the meanwhile, segregated classes should continue. ${ }^{65}$

NUC became a full-fledged university in 1950. The establishment of parallel institutions as envisaged by the 1945 subcommittee did not materialise, although a Medical School for Blacks was established. Vice Chancellor E. G. Malherbe appointed a commission to investigate the future academic, administrative, and financial structure of the university. The commission was made up of M.C. Botha and P.A. Duminy, and produced a report in 1951 that argued that the Black section was causing "dispersion of effort and activity” and was an intolerable burden on the staff; weekend sessions were "soul-destroying." The experiment could not be financially justified and the services rendered were of "questionable

\footnotetext{
${ }^{64}$ UN Archives File 13/13, Non-European SRC Correspondence, 1944.

${ }^{65}$ UN Archives File 13/13, Non-European SRC Correspondence, 1944.
} 
academic value.” The report suggested the creation of a separate, full-time and autonomous Black institution. The university's Senate and Council adopted resolutions which reflected agreement with the report, and called for the establishment of a separate institution for Blacks under the control of the University of Natal (UN). The Council declared, however, that it had no intention of closing the Black section in the immediate future. ${ }^{66}$

These developments were discussed at an emergency meeting of the Advisory Committee on Non-European Affairs on 26 September 1951. The committee recommended that the University appoint full-time staff for Black classes, with qualified Blacks considered for appointment. The committee hoped that personnel specifically appointed to assist the Black section would still be available except on weekends. It recommended further that weekend classes be taken by full-time staff appointed only for the Black section, or by anybody else who volunteered. It was also suggested that a course be offered only if there were a minimum of ten students. The following day NESC met in an emergency session. Palmer's memorandum to the meeting treated the two issues under discussion separately, namely the creation of a separate Black college, and the need for immediate relief to full-time lecturers involved in segregated classes. Full-time Black students could be accommodated at Wentworth then used for medical students. It was her opinion, however, that a separate Black college, if it was established, would have to operate on a part-time basis as most Black students were part-time and that is where the need was the greatest. As for providing immediate relief to full-time lecturers, she suggested cutting down on classes, regrettable though this would be. NESC agreed to Palmer's consulting with the various Boards of Faculties about the changes to be introduced for $1952 .{ }^{67}$

A Joint Committee of Senate and Council, on which both the Advisory Committee and NESC were represented, met in the weeks following the emergency meeting. This committee could apparently reach no decision as to a long-term policy, and so agreed that for the immediate future segregated classes would continue as in the past. A subcommittee met in October 1953 in response to a memorandum by J. D. Krige, and recommended that weekend classes be gradually phased out. ${ }^{68}$ The university integrated most of the part-time

\footnotetext{
${ }^{66}$ UN Archives, File 9/13, Advisory Committee to Council on Non-European Affairs. The committee report was not in the file, but a summary was given in a memorandum by J. McKinnel, G. H. Durrant, G. S. Nienaber, and J. D. Krige.

${ }^{67}$ UN Archives, File 9/13, Advisory Committee to Council on Non-European Affairs.

${ }^{68}$ UN Archives, File 9/13, Meeting of the Advisory Committee to Council on Non-European Affairs, 21
} 
Black division in 1960 and terminated them completely in May 1965. By then most of the classes had been phased out due to the opening of a separate university for Indians.

Why did segregated classes continue for so long given inherent weaknesses in the system and the unanimity of sentiments that they should be discontinued? The NUC, having decided in 1936 that Black students could not be accommodated in mixed classes, introduced a racial element from which it could not extricate itself. The National Party's coming to power in 1948 made integration more problematic. The Nationalist government in fact took the initiative by declaring its intention to extend segregation to all areas including university education under apartheid. Perhaps the NUC, like other English-speaking universities, did not take the government's intention seriously, as Margo Russell maintains, since, following the 1951 Eiselen Commission which recommended segregation, the 1953 Holloway Commission concluded that segregated universities would not be economically viable. However, a determined government appointed an Interdepartmental Committee that recommended the creation of segregated universities. It introduced the Separate University Education Bill in March 1957, appointed a Select Committee in July 1957 to conduct hearings, and reported a bill in August 1958. This bill became law in June 1959, and was designated as the Extension of University Education Act 45 of 1959. ${ }^{69}$

UN's segregated classes were not the same as apartheid's separate universities but Black students from the 1950s made little distinction between the government's aims and those implied in the declarative statements made by university's officials over the years. Malherbe defended "internal segregation" for the two decades that he was at the helm of the institution. Indeed, he said soon after becoming principal that he favoured a segregated campus for Blacks. The justification he introduced was that education levels for Blacks and Whites were different, and that the "traditions" of Whites would not allow mixed classes. He echoed the long-standing concern among Whites that admitting Blacks openly would lower

November 1951. UN Archives, 12/3, 18 June 1953, NESC, Krige’s memorandum, subcommittee’s report, 23 October 1953. The subcommittee members were T. Kelly, M. Palmer, B. Bopela, and Jack Naidoo.

${ }^{69}$ Margo Russell, "Intellectuals and Academic Apartheid, 1950-1965," in The Liberal Dilemma in South Africa, ed. Pierre L. van den Berghe (London, 1979), 133-52; Report of the Commission on Native Education, 19491951, UG 53/1951; Department of Education, Arts, and Science Annual Report for 1955, UG 20/1956; for recommendation of the Interdepartmental Committee see "Short Summary of the Interdepartmental Fact-finding Committee’s Findings”, W.P. c/1957. The Graphic, 6 February 1959, reacted in this way, "It is pathetic and inexplicable that the University, the highest pedestal of learning where good sense and understanding should be the guiding factors, should be riddled with discrimination on grounds of colour. It is the negation of the very principles for which a University is constituted and that people of enlightenment between man and man is definitely preposterous." 
academic standards. In July 1953, Malherbe told a BBC reporter that integration at UN would drive away "the cream" of White students. ${ }^{70}$ Malherbe wrote in 1957 in Science and Freedom that the frustration of Black students at the University was no "greater than that which they daily experience[d] under the prevailing mores of South African society outside the university”.

He was also opposed to races mixing on principle. M.J. Naidoo, president of the Black SRC in the 1950s, recalled how Malherbe made circles with different coloured pencils to illustrate how people of different colours could not mix. ${ }^{71}$ In 1959, even while arguing against racially segregated ethnic universities for reasons outlined below, Malherbe rejected mixed universities. He admitted that they could promote inter-racial contact and afford students the opportunity for mental stimulation, but in practice, such contact did not work out "so sweetly". There were social bars at mixed universities because the "mores" of Whites did not allow inter-racial mixing. Such a university could not go "the whole hog... Giving NonEuropeans a few social privileges and denying them others on the campus must inevitably increase the occasions when the Non-Europeans feel themselves discriminated against”. He would rather "reduce to a minimum the occasions when such friction may arise and give each group its own university campus”. ${ }^{72}$

Both Malherbe and the Nationalist government pointed to the segregationist ethos among Whites as justification for separate institutions. Indeed, the government wove around it an ideology. Apartheid's segregated universities were intended to promote racial and ethnic identities and to replicate segregation of the society at large. Malherbe sought to accommodate the need for a Black university within the ambit of what White prejudices would allow. That was the reason he disliked mixed dancing at university functions. Indeed, he did not like any mixing, although on one occasion in 1948 he approved of a White student studying with Blacks in Geography III because it was not offered to Whites that year. ${ }^{73} \mathrm{He}$ insisted on having separate SRC’s for Blacks and Whites even though Black students wanted

\footnotetext{
${ }^{70}$ UN History Department Archives, EGM 1/B/6; EGM 1/B/7, Malherbe Papers, 23 July 1953.

${ }^{71}$ Conversations, with M. J. Naidoo, 6 June 1985.

${ }^{72}$ UN History Dept. Archives, EGM/1/B/8, Malherbe's Comments on Extension of University Education Bill, 2 April 1959.

${ }^{73}$ UN Archives, File 8/13, Non-European Courses, Correspondence with students, 24 February, 1948; UN Archives, Files 13/13 and 29/15/5, Non-European SRC, see correspondence between the Black SRC and Malherbe between 1946 and 1949; UN Archives File 12/13, NESC, Correspondence to 1949, 24 May 1946; UN Archives, File 1/10/13, Natal University Development Fund Committee, AGM, 25 March 1946.
} 
a single body representing all students. There were three separate bodies, two for Whites, one each in Pietermaritzburg and Durban, and one for Blacks in Durban which had been created in September 1948. The three bodies sent representatives to a Joint Board. The principal was distinctly unhappy, however, when the board elected M.J. Naidoo as president in 1956-1957 with B. Pillay as secretary. ${ }^{74}$ Ann Stoler has mooted that in colonial settings power is often exercised through defining the "rule of normalisation". There is a language of difference that seeks to structure colonial orders and it includes discourses about things like pedagogy and respectability. A setting like the university is a micro-site where racial membership is designated through defining the distinctions of a White, bourgeois self. By focusing on Black students and their deficiencies or differences relative to Whites, the likes of Malherbe helped to maintain the cultural borders of White society. ${ }^{75}$

Malherbe also rejected the government's plans to segregate university education. In fact he did not see the need for it as this was precisely what the university had been doing. He wrote in 1961:

The Government's action has been justified on the grounds that it is supposed to be in line with the Government's policy of 'apartheid' in providing 'separate and equal' facilities for White and non-White university students. This is, however, exactly what the University of Natal has been trying to do with the limited means at its disposal over the last twenty-five years...[Our emphasis]. ${ }^{76}$

He favoured segregated campuses under the control of UN, a system that had distinct advantages. In a July 1947 article, Malherbe explained why, given an option from among separate universities, mixed universities, and the Natal experiment, he would opt for the latter. In a separate university, he said, Blacks could become aggressive and recalcitrant, and could easily be led astray by agitators. Besides, such an institution may have difficulty establishing academic credibility, and could be dismissed as mere dispensers of "nigger" degrees. $^{77}$ In February 1948, he presented similar arguments when he testified before the

\footnotetext{
${ }^{74}$ UN Archives, File 29/15/5, Non-European SRC, Meeting between Black SRC members and Malherbe, 11 December 1956. Conversations, with M. J. Naidoo, 6 June 1985.

${ }^{75}$ Ann L. Stoler, Race And The Education Of Desire: Foucault's History Of Sexuality And The Colonial Order Of Things. (Durham and London: Duke University Press,1995), 64 and 81.

${ }^{76}$ UN History Department Archives, EGM/1/E1/8, "University Education for Non-Whites: Recent Consequences of the Government Policy in South Africa,” 1961.

${ }^{77}$ UN Department of History Archives, EGM/1/B/5, Article in July 1947, "The Organisation for Non-European Higher Education”.
} 
Select Committee that was considering the University of Natal (Private) Bill. ${ }^{78}$ The Natal experiment, he wrote in 1961, was the most acceptable option. It aimed at "avoiding these undesirable consequences by keeping them [the Blacks] socially in separate and independent student communities and at the same time providing them with academic facilities which are equal in standard to that of the Europeans." 79 Malherbe conveniently glossed over the fact that Blacks had limited course options and terrible second rate facilities. Also, he reiterated this in his 1981 autobiography Never a Dull Moment where he wrote that he had "plenty of historical evidence to show that in isolated separate black institutions more fanatically antiEuropean agitators were bred that in mixed universities." 80

\section{Black Student Reaction to Segregated Classes}

While Black students expressed gratefulness to Palmer and others for their dedication, they were aware that segregated classes denied them equal access to the institution's facilities. Black students endeavoured to balance the benefits of education against the disabilities of segregated classes. Their exclusion from the Howard College campus was a serious grievance. Sir Sayed Raza Ali, the Agent-General, even mooted a boycott of the classes in $1936{ }^{81}$ In the end it was decided to accept the arrangement as a "necessary evil". Leo Kuper observed that student political attitudes were shaped by "racial discrimination in the wider society." ${ }^{82}$ Student perceptions were sharpened by an era of heightened political activities among Blacks from the mid-1940s. Individual Black students were members of the Indian and African Congresses, Non-European Unity Movement (NEUM), and Pan Africanist Congress (PAC); and participated in movements like the 1946-48 Passive Resistance and the 1952 Defiance campaigns. In addition, the Treason Trial from 1956-61 heightened their political consciousness.

As we saw earlier, two 1944 memoranda by students were inspired by the larger political forces. These sentiments intensified in the mid-1950s as the student profiles changed. Students were younger and, increasingly, more of them studied full-time. The

\footnotetext{
${ }^{78}$ UN Archives, SC 3/1948, Report of the Select Committee on the University of Natal (Private) Bill, 4 February 1948.

${ }^{79}$ UN History Department Archives, EGM/1/E1/8, "University Education for Non-Whites: Recent Consequences of the Government Policy in South Africa," 1961.

${ }^{80}$ E.G. Malherbe. Never a Dull Moment. (Cape Town: Trimmins Publishers, 1981), 301.

${ }^{81}$ Vietzen, “Mabel Palmer”, 102.

${ }^{82}$ Kuper, African Bourgeoisie, 153-66.
} 
Annual Report of 1955 recorded activities that show concern for wider issues: a student conference in Pietermaritzburg dealt with the topic, "What Segregation Does to Us"; in 1955 two students went as delegates to the Congress of People in Kliptown where the Freedom Charter was drafted; when the Joint Board decided to have separate ties for the different sections of the university, the Black SRC opposed the measure though it accepted the decision under protest. Students protested the closure of Fort Hare University College; and a copy of the Freedom Charter was placed on the notice board. ${ }^{83}$ Paul David came to university in 1959, and recalled:

\begin{abstract}
We were politicised even before we came to university, me through my father [Simon David, who graduated from NU in 1947 while a principal at Mount Edgecombe] who was a school principal, obviously my sister [Phyllis Naidoo] had an influence, and people we knew were in the Treason Trial. I.C. Meer was based in Verulam, J.N. Singh was a family friend ... all this brought to bear on us at Verulam High. Some of the lecturers [at university] were fine. John Neame was our history lecturer, a political person ... he was jailed with Sylvia Neame but the very fact that we were in a separate section politicised us. ${ }^{84}$
\end{abstract}

Even those who did not come with a highly developed political awareness were transformed by their experience. Sunny Venkatrathnam was born in Sea View in 1935. His schooling was interrupted by World War II but after the war he attended Stella Hill primary, "a totally Indian school, Indian teachers, everything Indian”. He completed standard six and attended Sastri College, "the only one in my family to go to high school... Same situation, Indian teachers, Indian students”. University was “a turning point in my life because up until then the same old attitudes about different people were pumped into us because the History books referred to Indians as Coolies, Africans as Kaffirs, and Coloureds as Boesmans....”. He recalls his reaction when he attended his first lecture:

To my absolute shock I saw about ten African students. I couldn't believe it. I had to blink a few times because up until then I was told that Africans had nothing between the ears and I believed it ... and by the end of the first lecture I was further shocked because these were the more articulate people in the class. I recall going home that night and telling my father. He was also shocked that there were Africans at university. [I] was angry against my parents, my school teachers and everybody, about misleading me. Then there were white liberals like Leo Kuper and C. K. Hill who became friendly, patronising, and I thought, good, because for the

\footnotetext{
${ }^{83}$ Annual Report of the Non-European SRC, 1955, File 29/15/5, UN Archives; conversations with D.K. Singh, 4 June, 1985, M. J. Naidoo, 6 June 1985, Pat Samuels, 7 June 1985, and Fatima Meer, 14 June 1985. In 1946 , Naidoo said that Blacks in Durban did not mind segregation as long as the "instructional service accorded to them [was] of the same standard.” His views changed later. See UN Archives File 8/13, Non-European Courses, Correspondence with Students, 24 February, 1948.

${ }^{84}$ Paul David, 4 November 2009. Interviewed by Goolam Vahed (telephonic).
} 
first time a White didn’t call me "Sammy”, ${ }^{85}$

For Thumba Pillay, now a Judge, university experience was crucial, especially in his decision to switch from teaching to law:

Once I got in, I realised the inequities of the system, that here we were going to a university studying after hours but not being admitted to the university itself, not sharing the facilities and the classes where Whites were tutored; not going to Howard College campus and so on. We were being taught in warehouses when there was ample accommodation elsewhere to accommodate us and to be taught with other people who were enjoying much better facilities. And then I realized, 'Look, if you are going to be a teacher, you are just not going to be able to fight this system.

In the 1940s people like Ashwin Choudree, M. D. Naidoo, J. N. Singh, and I. C. Meer studied at UN and provided political leadership in various capacities. In the 1950s a new generation of leaders was moulded at UN as some of the most committed individuals politically. The university was "a beehive of activity," according to Kader Hassim. The African National Congress Youth League (ANCYL), Natal Indian Congress (NIC), NEUM, and Society of Young Africa (SOYA), which had been formed by Leonard Nikani, Atkin Moleko, Justice Poswa, Don Kali, and Pat Naidoo, were active on campus. Phyllis Naidoo recalls that the "debates had Mac [Maharaj] on his feet against the NEUM ... Kader Hassim and Amanullah Khan and others.” ${ }^{86}$ SOYA produced a journal called the Voice of Student Letter which attacked university authorities. Students with NEUM leanings formalized themselves into the Durban Students Union under the presidency of Gora Ebrahim (later of the PAC) in the late 1950s. ${ }^{87}$ Those with Unity Movement leanings, according to Kader Hassim, included V. S. Rajah, Shirley Reddiar, M. C. Moodliar (now with Human Rights Commission), Iyavar Chetty (now with the Censorship Department), Navi Pillay, Sunny Venkatrathnam, John Samuels (South African Committee for Higher Education, Nelson Mandela Foundation, now at Oprah Winfrey school), Leonard Nikane, Bruce Mnguni, Ambrose Ndungane, Atkin Moleko (now Judge), and Justice Poswa (Senior Counsel).

On the Congress side were future anti-apartheid stalwarts the likes of Rabi Bugwandeen, Paul David, Thumba Pillay, Mac Maharaj, Galaki Sello, and Phyllis Naidoo. At the Medical School were Herbert Ushuokunze, who later became Minister of Transport in

\footnotetext{
${ }^{85}$ Gandhi-Luthuli Centre, 'Voices of Resistance Project'.

${ }^{86}$ Phyllis Naidoo, Footprints in Grey Street, (Durban: Far Ocean Jetty, 2002), 132.

${ }^{87}$ Interview with Goolam Vahed.
} 
Robert Mugabe government in Zimbabwe and Steve (Nunda) Naidoo who was with the first batch of Umkhonto we Sizwe recruits trained in China just before the Sino-Soviet dispute. Paul David recalled the political debates that followed the adoption of the Freedom Charter:

There was great debate who South Africa belonged to. Kutumela was a PAC man. He later qualified as an advocate and settled in Johannesburg. He was absolutely intelligent and highly articulate and held his ground. He was even offered the vice-presidency of the PAC while he was a student. The Unity Movement was opposed to us [Congress] and would ally themselves with PAC types over all issues. ${ }^{88}$

According to Sunny Venkatrathnam, the campus "became a very political body... Ideological debates were very, very intense. It was an invigorating situation”. He recalls that students "refused to stand when the principal addressed you on the first day of the term ... until eventually, they didn’t come to address us”. Through such activities, “student militancy and activism began to develop, began to grow." ${ }^{99}$ Much of this was re-played at the newly created University of Durban-Westville (UDW), for example, where students declared in 1972, "The denial of basic rights on our campus is only part of the campaign to perpetuate the subjugation of the black man by persistent attacks on his dignity."90

Nowhere was internal segregation more keenly challenged by Black students than at the annual graduation ceremonies. Graduating Black students were capped after White students and Black parents were seated at the back of the Durban City Hall where the graduation ceremony was held. Students found this humiliating. "In ordinary life,” Black students wrote to Malherbe as early as April 1945, "we meet segregation almost wherever we turn. Our colour is constantly thrust before us. Some had become hardened to it”, but they had become "very sensitive to this colour discrimination". They continued that at a graduation ceremony, "this discrimination is entirely uncalled for. We are extremely pained that it exists year after year. It wounds our susceptibilities deeply. It humiliates us. We appeal to you to remove it...”. The NESC, the Advisory Council, and the SRC Joint Board all protested but to no avail. Thereafter Black students engaged annually in a boycott of the graduation ceremony.

\footnotetext{
${ }^{88}$ Paul David, 4 November 2009. Interviewed by Goolam Vahed (telephonic).

${ }^{89}$ Gandhi-Luthuli Centre, 'Voices of Resistance Project'.

${ }^{90}$ See Natal Mercury 29 May 1972; Surendra Bhana, “University Education,” in South Africa's Indians: The Evolution of a Minority ed. by Bridglal Pachai (Washington DC: University Press of America, 1979), 384-440.
} 
In February 1951, sixteen graduates boycotted the ceremony, and explained that they wished to be treated as university graduates and not as "Non-Europeans." 91 Kader Hassim, a member of the Unity Movement who spent ten years of Robben Island, described the segregated seating as "Whites on the one side; Blacks on the other. Then they would call out the white graduates first. It was humiliating.” Hassim recalls that Black students generally boycotted the ceremony; a few graduated in absentia and were fined £3. ANC activist Phyllis Naidoo was one of them. She would recall,

\begin{abstract}
We had our own ghetto in the graduation hall [so] we chose to obtain the certificate through the post without the fanfare and insult of graduation. Malherbe said at a tea party he organized for all three SRC's that he did not understand boycott of graduation. I explained that my parents should choose their seats in the hall and not be pointed to a particular black section. $^{92}$
\end{abstract}

Eventually, the University offered a compromise in 1957. An integrated graduation ceremony where students would be presented in strictly alphabetical order with parents seated separately. "That was a bigger insult," according to Sunny Venkatrathnam, “and they thought they were relenting and doing us a favour by mixing the students but not the parents”. Students rejected the creation of three zones which were introduced in 1959, one White, one Black, one free. According to Hassim, the authorities offered:

....three blocks in the seating arrangement, one for Whites, one for Blacks, and a mixed area. And we said 'No, no, no, no to this Group Areas plan. It is all or nothing.' They even threatened that if we boycott, the government was going to close the university down. We were not deterred. ${ }^{93}$

In their actions, students were supported by the African National Congress (ANC) and NIC which declared in 1959 that the discrimination was "an insult to the dignity and selfrespect of the non-white parents, friends and relatives of the successful graduates.... There can be no justification for the maintenance of racial prejudice at an institution where the main criteria [are] the pursuit of truth and learning." 94 When the Black SRC met with Malherbe, he gave as one of his reasons for segregated seating that "Non-European parents were not as

\footnotetext{
${ }^{91}$ The 16 were R. Thumbadoo, Fatima Meer, Pramda Sobrun, M. Pothraju, R. Somaru, R.L. Naidu, N.G. Moodley, M. Ramsaroop, V. Nair, L. Gangoo, E.M. Naidu, Y.S. Naidoo, V.D. Naidoo, S.K. Naidoo, S.S. Singh, T.J. Maharaj; UN Archives, File 1/13,Main General File Non-European Section.

92 Naidoo, Footprints, 133.

${ }^{93}$ Gandhi-Luthuli Centre, 'Voices of Resistance Project'.

${ }^{94}$ The Leader, 6 February 1959.
} 
yet of the social standard to be seated with European parents.”95 Phyllis Naidoo recalled:

We went to Prof. Malherbe and Malherbe was saying, "I don't understand what you're fighting for, to sit next to white people. I said, "God forbid," you know, "is that all you understand about protest." I said, "You know, if you said nothing about where our people should sit, they would probably all go and sit with all the blacks because that's the place they're most comfortable. But when you tell us these eight seats whatever are reserved for blacks, then you are insulting us and we don't want it. My father was pleading with me to graduate. He says I want to see you graduate. I said, “No, dad, I can’t do it”. ${ }^{96}$

Students, according to Hassim, "carried on agitating until they finally caved in. The entire hall was totally unsegregated." ${ }^{97}$ Racial seating arrangement ended in 1962 but by then most students were being accommodated at the new university for Indians.

The boycott of the university's fifty-year Jubilee celebration in 1960 is illustrative of how deep the disaffection was among Black students. The festivity was not for them, "the oppressed," said the Durban Students’ Union (DSU). Black students had been part of the institution, to be sure but to what part of the university had they been assigned? Had they been accepted "as equal members in this 'House of Learning'”. "It is common knowledge," the students said, "that the non-white students were and are relegated to the backyard (Sastri College) and to the warehouse (Marian Buildings). Inferiority in facilities... limitations of courses of study... restriction of faculties... the crumbs from the tables of those who NOW want to celebrate." The DSU was openly scornful, "The ruling class, in its mad pursuit of maintaining white supremacy, is systematically down-trodding and enslaving the oppressed both physically and mentally..." and that these universities - "racial breeding grounds" and "graveyards for the intellectuals" - intended to produce "servile automatons”. Education could not be “divorced from politics", and called on all to unite for "democratic education". ${ }^{98}$

Kader Hassim also recalled that students were "galvanised by the Golden Jubilee celebrations of March 1960.” The response of Black students was, “No, for fifty years this was an apartheid university, and we are not taking part. Maybe there is history for you guys, but not us.” The elaborate programme included international celebrities like Edmund Hilary

\footnotetext{
${ }^{95}$ New Age, 31 March 1960.

${ }^{96}$ Noble, "Ruffled Feathers”,176.

${ }^{97}$ Gandhi-Luthuli Centre, 'Voices of Resistance Project'.

${ }^{98}$ Kuper, African Bourgeoisie, 157-158; Natal Mercury 29 May 1972; see also Surendra Bhana, "University Education," in South Africa's Indians: The Evolution of a Minority ed. by Bridglal Pachai (Washington DC: University Press of America, 1979), 384-440.
} 
and the Royal Ballet. Hassim takes up the story of the protest action:

\begin{abstract}
And that night, when they had a show, a Royal Ballet from Britain at the Alhambra Theatre, we placarded these people and embarrassed them with publicity. These were your so-called liberals who were at the head. It was raining that night, and the long sleek black limousines came, the Whites came with their bow-ties and tailcoats, the women with the fancy gowns, and next thing we unfolded our banners and placards. They were greeted by a long row of placards - 'The jubilee of an Apartheid University;' 'If gold can rust what will iron do.' And Professor Elizabeth Sneddon was furious because she was embarrassed tremendously. Of course, the students gave it back to her in kind also. ${ }^{99}$
\end{abstract}

In his autobiography, however, Malherbe remembered only that the newspapers "carried headlines lauding the 'Glittering Opening of University's Jubilee.' The opening night was indeed a scene that recalled the splendour of bygone days with all the men in white eyes and the ladies in full evening dress". The only occasion that Malherbe could recall having a runin with Black students was when Sir Alexander Carr-Saunders of the London School of Economics visited Durban to give a College Lecture. Malherbe arranged an evening lecture at the City Building "because it was not easy for non-whites to get transport at night to the university on the Berea”. Black students boycotted the lecture, "apparently assuming that this was pandering to the apartheid policy of the government. Obviously, I found it most embarrassing that these non-Whites should have treated such a distinguished guest speaker in this way”. Malherbe added, “As far as I can remember this was the only open confrontation I had with students during the twenty one years that I was Principal.” ${ }^{100}$ This was not what Black students remembered.

When the apartheid state passed the Extension of Universities Education Act, which sought to entrench the idea of racially segregated universities, it galvanised students from all over the country. They descended on Cape Town and marched to Parliament, to take part, according to Sunny Venkathrathnam, in "a torchlight procession through the streets of Cape Town. We were arrested, put on the train and sent back to Durban. There were very many protest meetings and petitions against separate universities.”101

In 1960 the government proposed a university for the exclusive use of Indians as part of the apartheid design to prevent Indians from attending White and even African

\footnotetext{
${ }^{99}$ Gandhi-Luthuli Centre, 'Voices of Resistance Project'.

${ }^{100}$ Malherbe. Never a Dull Moment, 315, 301.

${ }^{101}$ Gandhi-Luthuli Centre, 'Voices of Resistance Project'.
} 
universities. As more young people were finishing high school, the demand for university education became more insistent. Without prior consultation, Minister of Education J.J. Serfontein simply announced that in terms of the University Education Act of 1959, he had established a separate Indian university as from 1 November 1961. This announcement drew students in protest and in what was a rare occurrence, brought together political adversaries among Indians from the moderate Natal Indian Organisation (NIO) to the more radical NIC, which rejected the proposal. Dr. Monty Naicker, president of the NIC, condemned the "highhanded" attitude of government in not consulting with the community. He said that "the university is a temple of truth, and knowledge should be imparted with no regard to a person's race, colour or creed or financial standing. The sole factor governing admission should be merit." 102 Naicker and P. R. Pather of the NIO issued a joint statement that "there are no two viewpoints in our community... We are completely unanimous in our condemnation.” S. M. Mayet, senior vice-president of the NIC, addressing a meeting of the Liberal Party in Durban in November 1960, "rejected a Trojan horse which is contrived to cultivate warped minds”. ${ }^{103}$ The location for the university was carefully chosen, Salisbury Island, a place that students would have to access by ferry, making it a site where freedom of movement and speech could be more easily controlled. ${ }^{104}$

A conference of 200 delegates representing 50 organizations was held in Durban on 17 December 1960. Speakers included Monty Naicker, A. M. Moolla of the NIO, Dr. A. D. Lazarus of the Natal Indian Teachers' Society, Ebrahim Ebrahim of the Natal Indian Youth Congress, and Thumba Pillay of the SRC of the UN, Dr. Alan Paton, and Professor Leo Kuper. M.D. Naidoo moved a motion, seconded by A.M. Moolla, calling on Indians not to serve on the Indian University Advisory Council; Whites to understand "the feelings of the Indian people and refuse to serve on the council"; teachers who "treasure the true traditions of a University to recognise the importance of not accepting any teaching post;” and parents and students to "explore alternate possibilities as far as possible" for university education. ${ }^{105}$ When it was announced that Mr. Nattrass, Principal of the M.L. Sultan Technical College, and Colonel Butler Porter had agreed to serve on the Council of the new university, Monty Naicker announced that if they had "the interest of the Indian people at heart, and knowing

\footnotetext{
102 Graphic, 4 November 1960.

${ }^{103}$ New Age, 10 November 1960.

${ }^{104}$ Graphic, 4 November 1960.

${ }^{105}$ New Age, 5 January 1961.
} 
that the entire Indian community is opposed... they should resign from their positions”. ${ }^{106}$ This mobilisation failed to stop the opening of the Indian University but showed the depth of opposition to racially segregated education.

The opening of the Indian university ended an experiment in providing "separate and equal” education for Blacks in a segregated environment. The UN recognized the weaknesses inherent in the experiment, but argued that the "mores" of the White people would not allow for integrated classes. In the end it scrapped segregated classes not because the mores of Whites had changed, but because the political dynamics surrounding university education altered dramatically. The prospect of Blacks inundating the university diminished as the state compelled them to enrol at the newly created racial institutions. Its rationale for creating and maintaining segregated classes flowed from structural inequalities of an unequal society, and mirrored the practices and policies of Natal's educational system whose foundation lay in racial superiority. ${ }^{107}$

\section{Conclusions}

The provision of segregated classes at Natal University must be seen within a broad context. It sprung from a rigid political ideology; segregated classes were improvised for practical reasons, but they also sprang from a history of treating Blacks differentially in which some university officials and academics conveniently hid behind an ill-defined White ethos. Many former students were disillusioned by their experience at UN and believed that university officials acquiesced unnecessarily to racism rather than confronting and challenging it. Their criticism pointed to the limits set by White liberals at the university and, in particular, their reluctance or inability to challenge segregationist structures in any fundamental way. Kader Hassim described segregated classes as “a piece of sordid history. They did not even want Blacks to wear the same blazer.” Sunny Venkatrathnam said that the experience caused him to lose faith with some of the liberals at the university:

Natal University, at that time, was controlled by the Liberals, both in the big letter Liberal and the small letter liberal. The principal was E.G. Malherbe, a liberal. Senate, the chairman was Alan Paton, a Liberal Party man. On Council were people like Leo Kuper, C.K. Hill, and

\footnotetext{
${ }^{106}$ Graphic, 25 November 1960.

${ }^{107}$ Paul Thompson, “Schools, Sport and Britishness: Young White Natal, 1902-1961”, South African Historical Journal 45, November 2001, 223-48.
} 
leading liberals of the Liberal Party were on the governing body. And these were the people that saw it fit not to allow black people onto their campus. During those years [until 1959], there was no law on the statute which prevented white universities from accepting black students. $^{108}$

Navi Pillay was born in 1941 in Clairwood, an Indian working class area. Her education was paid for by bursaries from the local community on the initiative of her school principal. She became the first Indian girl to go to university from Clairwood. She registered for a BA degree at the university which she described as a:

...potato warehouse in Warwick Avenue... We really had to put up with racist lecturers [although] there were some good individuals... The university did not want black students to go any further than arm's length in education... and we were supposed to be very grateful for this separate education we were receiving. ${ }^{109}$

To be sure, the university facilitated the emergence of a class of Black intelligentsia and professionals, especially doctors, lawyers and teachers, who played important roles in their community. Many of them became active in politics. Sunny, for example, pointed to the university as a turning point in his political activism. Navi Pillay emerged from the system to become the UN Commissioner for Human Rights in June 2008. Many students who went through the university portals distinguished themselves in the liberation movement, and today enjoy a prominent position in its history. The university trained them for a life of political activism and dedication to the welfare of all South Africans. Some of the individuals are: Iyavar Chetty, Paul David, Gora Ebrahim, Aziz Hassim, Kutumela, Mac Maharaj, Fatima Meer, Bruce Mnguni, Atkin Moleko, M.D. Naidoo, Phyllis Naidoo, Ambrose Ndungane, Leonard Nikani, Navi Pillay, Thumba Pillay, Poswa, John Samuels, Galaki Sello, Herbert Ushuokunze and Sunny Venkatrathnam. Many of them went into exile, some joined the MK, and other spent years in jail at Robben Island.

When Mabel Palmer died in 1958, the NIC publicly recorded its appreciation for her "written endeavours to enlighten the people of South Africa and abroad in regard to ... Indians [in] South Africa and their early history and contributions...”. ${ }^{110}$ In a front page editorial, Leader wrote of the passing of "a friend and a benefactor":

\footnotetext{
${ }^{108}$ Gandhi-Luthuli Centre, 'Voices of Resistance Project.

${ }^{109}$ Gandhi-Luthuli Centre, 'Voices of Resistance Project.

110 This was in reference to her book History of Indians in South Africa. Quoted in Meer, “I Remember,” 491.
} 
She was a person who proved in her own life that racial barriers can be transcended by those who have goodwill and great hearts. She was a pillar of strength to those striving for higher education... almost to her dying day she worked ceaselessly for the advancement of university education for non-white students in Natal... were it not for her immense energies and unlimited sympathy for the cause of higher education for non-Europeans in Natal, hundreds of professionals, teachers and students would have been without university education. ${ }^{111}$

These sentiments about Palmer and the appreciation expressed by Black students are not contradictory to the stance they adopted on segregated classes. Forces outside of the university combined with resentment for segregated classes to politicize generations of Black students. Neither Palmer nor Malherbe could have prevented that. Black students demanded higher education as their right free from its racialized parameters. Brookes's insights are that while education "was a gift beyond price" to many Blacks in the formative period, "in later years... it [was] not possible to avoid regretting the failure of the university ever to concede real unhindered equality to non-European students.... What was given to non-Europeans was given sometimes with hesitancy and reservations, often too little and almost always too late.” ${ }^{112}$ Shula Marks wrote in respect of the relationship between Mabel Palmer and Lily Moya that "despite the gulf between the vision (of the Cape liberal tradition) and the practice... it was only a later, Black Consciousness generation [that] questioned the validity of the vision.” ${ }^{113}$ In the case of Natal, however, Black students and activists questioned this gulf between vision and practice, as regards segregated classes, from the beginning. They felt that the university could have done a lot more to integrate the institution. In many ways this was the legacy of White liberals was that they did not aggressively question segregation in principle. Maurice Webb told Sir Raza Ali when the latter threatened to encourage students to boycott the segregated classes in 1936, “The principle of segregation was already established and would not be appreciably strengthened by the new classes.” ${ }^{114}$

However much liberal pragmatists like Palmer and Malherbe argued the case for segregated classes, they worked within the existing racialised parameters rather than challenge them. Malherbe in particular was guilty of paternalism that bordered on racism. It was, as Martin Legassick argues, White liberals failed to step "outside the assumptions of segregation.” ${ }^{115}$ In his studies Racist Culture and The Racist State David Theo Golberg has

\footnotetext{
${ }^{111}$ Quoted in Meer, “I Remember,” 491.

112 Brookes, History of the University of Natal, 77.

${ }_{113}$ Marks, Not Either an Experimental Doll, 18.

${ }^{114}$ Quoted in Vietzen, "Mabel Palmer”, 105.

${ }^{115}$ Martin Legassick, 'Race, Industrialisation and Social Change in South Africa: The Case of R.F. A. Hoernie,' African Affairs, vol. 75 (April 1976): 224-239, 237; Quoted in Vietzen, “Mabel Palmer”, 105.
} 
argued that racism was central to modernity and that the chief culprit in this project has been the philosophy of liberalism which, as modernity's definitive doctrine of self and society, promised liberty and equality for all, but simultaneously rationalized and legitimated racist exclusion and racial inequality. ${ }^{116}$ NU became a site where racial membership was both produced and contested. Rather than tackle issues inherently part of a racially amalgamated university, the administrators took what they considered to be a practicable option at the time but one which arguably proved harmful in the long run. Had the university attempted to take a bold step much earlier, it may have been closer to finding a system that worked in a racially mixed environment with students who, since the 1990s, have been pouring into the institution with varying educational experiences and backgrounds to an integrated setting. The University of KwaZulu-Natal system continues to struggle to address these issues.

\footnotetext{
${ }^{116}$ See chapter 2, Racist Culture. Philosophy and the politics of Meaning. Oxford: Blackwell, 1993 and chapter one, The Racist State. Oxford: Blackwell, 2002.
} 